\title{
FOOD ALLERGENS AS AN ISSUE OF A "SUCCESSFUL" HOSPITALITY BUSINESS
}

\author{
Bojana Kalenjuk', Radoš Grče', Predrag Tošić", Dragan Tešanović'
}

Received: February 152017 | Accepted: June 27, 2017

\begin{abstract}
Choosing and consuming food in a restaurant, the guest (consumer) also participates in the creation of experience. This experience should be positive and be a pleasure for all senses in order for the guest toreturn to the same hospitality facility. However, for people who are allergic to foods, the choice and consumption of food in hospitality facilities can turn to negative experience, lead to fear, and even to negative or fatal reactions and consequences. That is exactly what can make successfulbusiness difficult for the hospitality facility, given that the number of food allergens is increasing every day as well as the number of guests with such problems. The paper has a task to examine the challenges faced by hospitality facilities in the area of the city of Novi Sad, to which they can respond, and to which they would like to respond when allergens are concerned.
\end{abstract}

Keywords: food, nutrition, allergens, hospitality industry

\section{INTRODUCTION}

Only a satisfied guest can provide a profit to a restaurant. That is exactly what is getting harder every day. The specific requirements they carry with them are becoming more and more numerous every day, and these are due to various factors, which are often unknown to them(Stojanović i Tešanović, 2005; Gagić et al., 2011; Carvalho de Rezende, Silva, 2014; Gagić et al., 2014; Cvetkovic et al., 2016). What surely complicates successful business are allergens (Bailey et al., 2011;Aleksić et al., 2015).

Flour, milk and eggs were until recently the most common food allergens. Today, their range is much larger except for 14 most prevalent. In order to overcome the problem of preparing food for people who are allergic to some of the ingredients, understanding food or knowing its composition requires detailed controls that can reduce the risk, as well as tools that can verify adequate control, which is highly complex (Kim et

\footnotetext{
University of Novi Sad, Faculty of Scinces, Department of Geography, Tourism and Hotel Management, 3 Trg Dositeja Obradovića, 21000 Novi Sad

" Faculty of Tourism and Hospitality, University of Business Studies, Banja Luka, Bosnia and Herzegovina, contact: pedjat8o@gmail.com
} 
al., 2005).The number of food allergies every day grows and makes it difficult for hospitality staff to look at all segments in preparing food and drink to eliminate their presence. The first step in their overcoming is the knowledge of their composition, that is, compounds that cause allergic reactions, because these are notonly proteins.

In food preparation in the hospitality industry, it is necessary to ensure food safety through the whole production chain: supplier - producer - distributor - consumer. Food business operators must further ensure that all phases of production, processing and distribution of food, which are under their control, meet the hygiene requirements laid down in the Act. They must also establish and implement regular controls of hygienic conditions at all stages of production, processing and distribution of food, except for the change of primary production and related activities, in each facility under their control, by implementing a self-regulatory preventive procedure developed in accordance with the principles of hazard analysis and critical control points. Each hospitality facility must be ready for certain modifications of the business mode, that is,food preparation in order to adequately remove the allergen from the food offered to the guest.

The subject of the paper are food allergies faced by the hospitality staffcausing them great problems because they are often not sufficiently prepared and educated to respond to the requirements of guests with these problems.

The task of the paper is to investigate the problems associated with allergens faced by the hospitality staff.

The aim of this paper is to determine the most common allergens and the need for education for their overcoming, all for the purpose of a successful business.

\section{LITERATURE REVIEW}

\section{ALLERGY AND FOOD ALLERGENS}

Allergy-causing substances are called allergens, and by their way of getting into the body, they are grouped into several groups. Although in the hospitality industry, the threat can also be respiratory allergens, contact allergens, and the like, the main problem are nutritional allergens that enter the body through food. It is estimated that about $30 \%$ of the population has proneness for allergic diseases, and this number is expected to continue to rise in the future (Lockey, Ledford, 2008;Pawankar, 2013).

For hospitality staff it is important to note that when the body of the hypersensitivet person guest comes into contact with an allergen, within minutes or hours, the symptoms of the allergy will be manifested(Mušić, 2009).All symptoms can be manifested in a mild form when they do not disturb work ability, but also in severe forms, and even dramatic forms when they endanger life (in case of choking, anaphylactic shock, etc.).(Hey, Luedemann, 2001; Lockey, Ledford, 2010; Martin, 2014).

It is important to distinguish an allergy from food intolerance, which implies the inability of an organism to digest certain foods, it is mostly lactose (milk sugar) and celiac disease whose frequency is increasing (Sichereret al., 2010).Allergy to particular foods 
requires constant attention in choosing food, which leads to social restrictions and rare visits to restaurants (Wanich et al., 2008). The most common problem is to determine whether the food they order absolutely does not contain the ingredients that cause their reaction (Leftwich et al, 2010).It is important to note that this is about a permanent contact of food with an allergen, not a contamination that can be mitigated by a certain treatment (thermal), such in the case with some microorganisms(Nollet, van Hengel, 2010).

\section{SYMPTOMS OF FOOD ALLERGY}

Although allergic reactions may occur to every food, most reactions occur to a small number of foods: milk, eggs, fish, shells, soybeans, wheat flour, walnuts and other nuts and berries (Thurnell-Read, 2005). Allergic reactions occur from a few minutes to a few hours after taking the food that the person is allergic to. In particularly sensitive people, only the smell or touch of food can cause an allergic reaction. The same type of food can lead to different symptoms in different people, but different types of food can lead to similar symptoms in the same child

Allergic reactions occur in a few minutes to a few hours after taking the food that the person is allergic to. In particularly sensitive people, only smelling or touching the food can cause an allergic reaction. The same type of food can lead to different symptoms in different people, but different types of food can lead to similar symptoms in the same child (Hey, Luedemann, 2001; Jones, 2001; Jedrychowski, Wichers, 2009; Pascal, 2012).

\section{THE FOOD THAT USUALLY CAUSES ALLERGY REACTIONS}

The most common fourteen types of nutritional allergens that can be found in foods are: peanuts, walnuts, crabs, shells, sea fish, eggs, milk, cereals, soybeans, sesame, celery, mustard, lupine and sulfur dioxide (Raljić, 2016).Increasingly common are allergies to red meat, river fish, special fruits and vegetables, as well as coffee, cocoa and salt.

Allergic reactions to foods are often caused by certain additives, preservatives and colors. Reactions to food additives occur in about $1 \%$ of children and in 0.01 to $0.23 \%$ of adults. Some of these substances are: sodium benzoate, tartrazine color (yellow colored beverages, sweets, etc.), aspartame sweetener (Pascal 2005; Pascal, 2009; Nollet, van Hengel, 2010).

\section{RESEARCH METHODOLOGY}

After reviewingnational and foreign literature, the research was conducted by conducting interviews with managers and chiefs of restaurants in Novi Sad. The research will use a descriptive method. The interview is one of the most commonly used research procedures for data collection, but for this type of research it also seemed to be the most suitable because it involves the interaction between the examiners and the respondents, and thus it gives the most reliable data. 
A direct interview was conducted in 12 restaurants. The interview consisted of questions about what specific needs have their guests and what needs they can respond to and whether they feel the need for information or training in order to respond to the needs of their guests when allergens are concerned. The obtained results were processed using descriptive statistics and presented in the paper through tables and graphs with the discussion.

\section{RESULTS AND DISCUSSION}

\section{ANALYSIS OF THE MOSTCOMMON FOOD ALERGIES}

By conducting research among hospitality facilities through interviews with managers and chiefs of restaurants in the territory of the city of Novi Sad, it has come to the finding that no facility can meet all the requirements of consumers, but that they have faced with all the requirements, as can be seen in the Table 1 .

All restaurant managers (100\%) have faced with requirements for the omission of foods containing gluten in their dishes, or with the requirements for celiac disease, but only $25 \%$ of restaurants can respond to these requirements, and $75 \%$ of restaurants would like to have knowledge and conditions. The chiefs stated that cooking staff used rice flour or corn flour as a substitute for wheat flour. As a problem in the preparation of dishes, they emphasize the inability of detailed monitoring of the possibility of food contamination, because flour particles can come to a dish by air.

When it comes to cow's milk, $50 \%$ of respondents faced with requirements, of which $33 \%$ of restaurants have lactose-free dishes in their offer, and 33\% would like to have such dishes, which is not so difficult to perform. To eliminate eggs, $66 \%$ of respondents expressed specific needs, while the needs can besatisfied by $50 \%$ of restaurants, and $42 \%$ of respondents say they would like to be able to respond to the needs of guests, so only one restaurant can not and does not feel the need to respond to the demands of guests.

In $50 \%$ of the surveyed restaurants, guests noted the allergy to fish dishes, while only $16 \%$ can satisfy their needs, and $66 \%$ would like to have the conditions and knowledge to respond to this need. A group of dishes related to fish dishes are dishes including shellfish and crabs, 33\% of restaurant managers said that they faced with guests' requests, $50 \%$ said they could respond to these requests, and $25 \%$ would like to have conditions.

Requests for the omission of peanuts from meals were found in $25 \%$ of hospitality facilities, $25 \%$ observed these needs and cansatisfy them, while $42 \%$ would like to have the knowledge and initiative to prepare meals for which they can guarantee that do not contain peanuts not even in traces. When it comes to walnuts, $25 \%$ of respondents have faced with requirements, $25 \%$ can satisfy needs, and $25 \%$ would like to be able to respond to the expressed needs of guests. The allergy caused by the consumption of other nuts, i.e. almonds, hazelnuts and pistachios, was mentioned by $33 \%$ of the managers of the facilities as a requirement of their guests, $25 \%$ can guarantee the quality of the service through preparing this meal to their guests, and $25 \%$ would like to acquire knowledge and conditions. 
Table 1. Needsof guestsfor omission of the food they are allergic to

\begin{tabular}{|c|c|c|c|c|c|c|}
\hline \multirow[t]{2}{*}{$\begin{array}{l}\text { Types of } \\
\text { allergens }\end{array}$} & \multicolumn{2}{|c|}{$\begin{array}{c}\text { Requirements - } \\
\text { needs for omission of } \\
\text { allergens }\end{array}$} & \multicolumn{2}{|c|}{$\begin{array}{c}\text { The needs of guests to } \\
\text { which restaurants can } \\
\text { respond }\end{array}$} & \multicolumn{2}{|c|}{$\begin{array}{l}\text { Allergens for which } \\
\text { they would like to have } \\
\text { the possibilities and } \\
\text { knowledge to eliminate } \\
\text { them from required } \\
\text { dishes }\end{array}$} \\
\hline & $\begin{array}{l}\text { Number of } \\
\text { restaurants }\end{array}$ & $\%$ & $\begin{array}{l}\text { Number of } \\
\text { restaurants }\end{array}$ & $\%$ & $\begin{array}{l}\text { Number of } \\
\text { restaurants }\end{array}$ & $\%$ \\
\hline $\begin{array}{l}\text { Gluten (wheat, } \\
\text { rye, barley, oat) }\end{array}$ & 12 & 100 & 3 & 25 & 9 & 75 \\
\hline Cow's milk & 6 & 50 & 4 & 33 & 4 & 33 \\
\hline Eggs & 8 & 66 & 6 & 50 & 5 & 42 \\
\hline Fish & 6 & 50 & 2 & 16 & 8 & 66 \\
\hline Shellfish, crabs & 4 & 33 & 6 & 50 & 3 & 25 \\
\hline Peanuts & 3 & 25 & 3 & 25 & 5 & 42 \\
\hline Walnuts & 3 & 25 & 3 & 25 & 3 & 25 \\
\hline $\begin{array}{l}\text { Other nuts } \\
\text { (almonds, } \\
\text { hazelnut, } \\
\text { pistachios) }\end{array}$ & 4 & 33 & 3 & 25 & 3 & 25 \\
\hline Soybeans & 2 & 16 & 1 & 8 & 4 & 33 \\
\hline Sesame & 3 & 25 & 2 & 16 & 1 & 8 \\
\hline Celery & 4 & 33 & 4 & 33 & 2 & 16 \\
\hline Mustard & 2 & 16 & 2 & 16 & 5 & 42 \\
\hline Lupine & 1 & 8 & 1 & 8 & 0 & 0 \\
\hline $\begin{array}{l}\text { Sulfur dioxide } \\
\text { and sulphites }\end{array}$ & 1 & 8 & 0 & 0 & 0 & 0 \\
\hline
\end{tabular}

Source: Research by the author

Soya is often used as a substitute for animal proteins, and is found in the traces of various food products, only two restaurants or $16 \%$ of respondents reported the need for omission, one of these restaurants can respond to needs, and 33\% would like to, among them, one is the facility with the manager pointing out that he faced the request, but he could not meet the guest's request.

Omission of sesame is requested in $25 \%$ of the surveyed facilities, two restaurants are ready to prepare meals, and one restaurant would like to have the knowledge and equipment for it.

Celery would be left out from the food by guests of $33 \%$ of the surveyed hospitality facilities, and $33 \%$ are willing to help the guest with such a request, while $16 \%$ are interested in information on how to help the client if they face this request.

Mustard is widely used as a foodstuff, and in $16 \%$ of the facilities there is a demand for the omission of this food from the preparation of meals, and also those respondents 
pointed out that they are ready to replace and leave out the mustard from preparation of specialties, $42 \%$ of the chiefs pointed out they would like to be prepared if they face this request.

Two causer of allergic reactions encountered at least are lupine and sulfur dioxide. Lupine is known as a plant that can effectively replace soya, due to its high protein content, and is therefore often an integral part of various sausage products. Sulfur dioxide $\left(\mathrm{SO}_{2}\right)$ and sulphites are additives from the group E 220, E 221-228 and are used in the conservation of fruits and vegetables, brandy and wine. Requests for the omission of these two ingredients were found in one facility. When it comes to lupine, the manager of the facility where the need for its omission was noted, points out that this is possible, while the manager of the facility where a guest pointed out the sensitivity to sulfur dioxide says that, unfortunately, they can not respond to this need, due to rare requests and knowledge of these foods as allergens; no manager pointed out that they would necessarily like to bother their staff with the knowledge, that is, to spend funds in the procurement of equipment or foodstuffs that would effectively solve the problem. It is important that it is enough to follow only the detailed declarations of products they purchase for the preparation of meals which must indicate ingredients, which is much easier than preparing gluten-free foods.

As a weakness, hospitality professionals cited insufficient information about the most common allergens, as well as a desire for information through a training that would be organized in the form of learning about the most common food allergens and the ways in which they influence, and that it might seem incentive to supplement their restaurant offers with more diversified dishes. When serving guests who are allergic to a particular food, the guest emphasizes their allergens and there is a lot of attention in the transmission of information. However, restaurants often do not have standardized working procedures neither recipes, they do not have any special food preparation facilities, thus, contamination easy happens. Hospitality workers are not enough educated about health needs of certain group of patients, but through clear guidelines of guests they try to meet these requirements, which does not guarantee safety.

\section{ANALYSIS OF SPECIAL REQUIREMENTS OF CONSUMERS IN TERMS OF ALLERGENS}

Observing requirements of consumers presented in Figure 1, it can be concluded that the most common requirements are gluten-free foods (20\%), followed by eggs (14\%), milk and sea fish, with all other cases encountered much less by hospitality workers.

\section{ANALYSIS OF POSSIBILITES FOR FOOD PREPARATION WITHOUT ALLERGENS}

Taking into account only the word of the manager and the chef as a responsible person, without detailed control, it can be concluded that restaurants mostly can respond to the needs of consumers who are allergic to eggs and sea fish (15\%), which together with other possibilitiesis shown in Figure 2. 


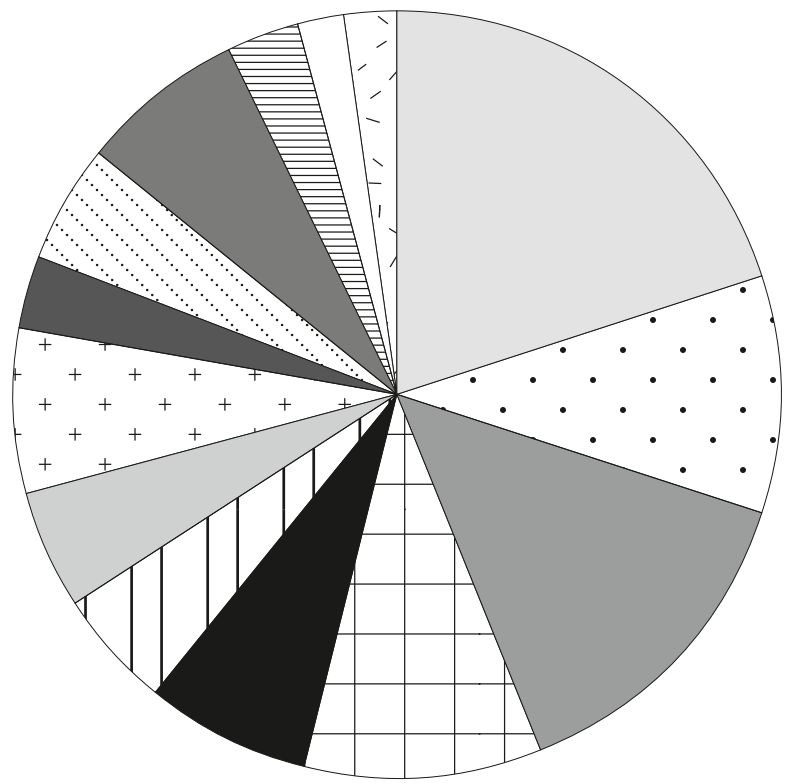

Gluten

$\odot$ Milk

Eggs

$\bigoplus$ Sea fish

Shells

(1) Peanuts

Walnuts

( Nuts

Soya

$\because$ Sesame

Celery

$\vartheta$ Mustard

Lupin

(-) Sulphur

Figure 1. Requirements for the omission of food allergens

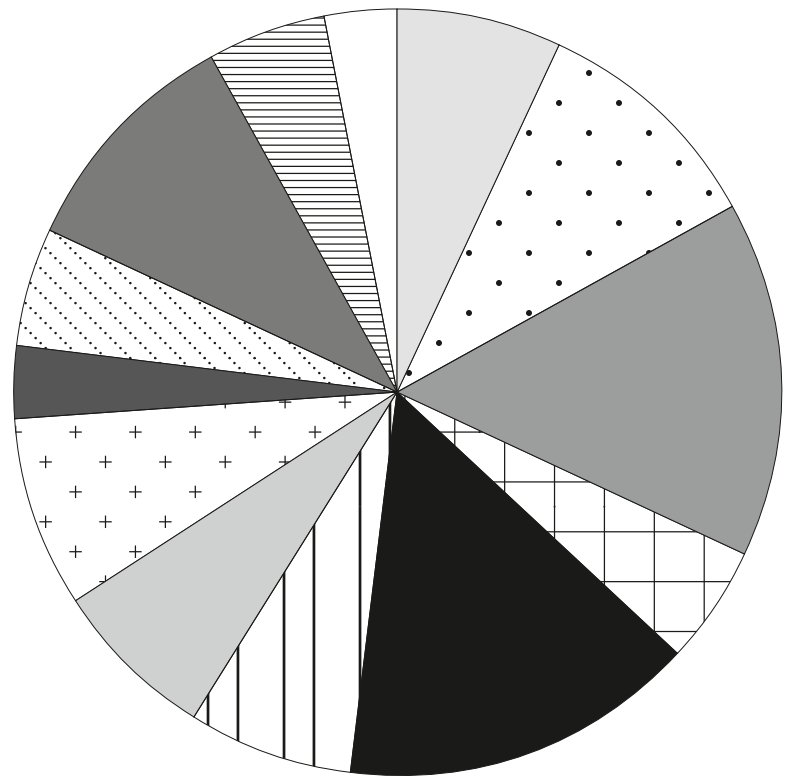

Gluten

$\odot$ Milk

Eggs

$\theta$ Sea fish

Shells

(1) Peanuts

Walnuts

(†) Nuts

- Soya

$\because$ Sesame

Celery

$\vartheta$ Mustard

Lupin

(-) Sulphur

Figure 2. Possibility of preparing meals without certain allergens 


\section{ANALYSIS OF THE MANAGEMENT WISHES TO RESPOND TO SPECIAL REQUIREMENTS FOR FOOD WITHOUT ALLERGENS}

Looking at the results of the first two figures, it is noticed that managers of facilities that do not have the knowledge and resourcesto eliminate gluten would like to acquire them, which is commendable. In addition, a large number of respondents are interested in acquiring knowledge and possibilities to eliminate fish and mustard as allergens, both because of their frequent use, and because their replacement is difficult.

Figure 3 shows the percentage of respondents wanting to have the knowledge and resources to respond to the demands of their guests, where the emphasis is givento gluten and sea fish, as well as preparation of dishes without peanuts, mustard, eggs and milk.
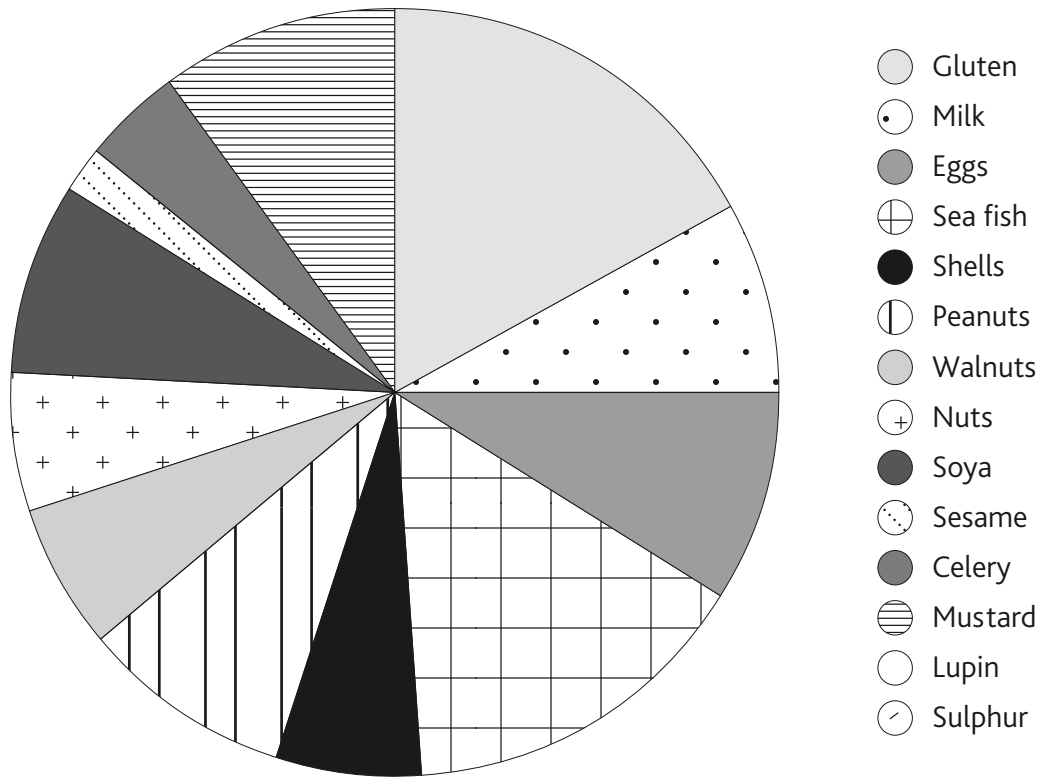

Figure 3. Allergens for which they would like to have the conditions and knowledge to omit

\section{CONCLUSION}

Based on the reviewed literature in the field of modern trends in thehospitality industry and allergens asa key issue, the conducted research on the territory of the city of Novi Sad gave the following findings:

- Allergy to gluten is the most common problem of successful business in $100 \%$ of surveyed facilities, while allergy to eggs (66\% of respondents), and allergy to cow's milk and fish (50\% of those surveyed) fall into quite often problems, unlike allergies to lupine or sulfur dioxide which are barely known to hospitality workers.

- What is commendable is that most of those who reported requests could respond to them. This, however, is not the case with gluten, which due to the fact that it can 
be found in the air constitutes an allergen difficult to avoid, so only $25 \%$ of the respondents can respond with the omission of gluten. However, in the case of other allergens, only some respondents pointed out that they were unable to satisfy the needs of the guests, or for some types of allergens, all who faced with them, they also could omit them for the needs of the particular guest.

- It is also commendable that a large number of hospitality facilities that have not faced with the requirements for omission of certain allergens would like to be ready for such a situation if it happens. There is also a desire to acquire knowledge and possibilities to meet those requests of guests that could not be previously met. All 75\% of those who are not able to respond to gluten-free needs would want to. And with most other allergens, managers and chiefs have shown their interest in responding to the requirements of guests in the most efficient way. However, there is still not enough information among managers and chiefs, and especially among staff about what allergens are, which are the most common allergens and how to replace or omit them. Solutions for such situations were known to managers or certain experienced individuals, while most were rather uninformed and unprepared. For this reason, it is necessary to work with the staff as well as with managers, to transfer information to them because the health for an individual is the most important and the hospitality facility as a place of enjoyment should not be a source of harm to health.

\section{ACKNOWLEDGMENT}

The paper presents the results of the research on the projects: III-046009 and 046005 financed by the Ministry of Science and Technological Development of the Republic of Serbia, and 142-451-2669/2017 financed by the Provincial Secretariat for Higher Education and Scientific Research.

\section{LITERATURE}

Aleksić, M., Popov-Raljić, J., Milanović, S. (2015). Alergeni kao hemijski rizici u sistemu bezbednosti hrane u ugostiteljstvu i njihovo označavanje, Hotellink, 25-26, 247-256. Bailey, S., Albardiaz, R., Frew, A. J., Smith, H. (2011). Restaurant staff's knowledgeof anaphylaxis and dietary care of people with allergies. Clinical and Experimental Allergy

Carvalho de Rezende, D., Silva, M. (2014). Eating out and experiential consumption: a typology ofexperience providers. British Food Journal, 116/1, 91 - 103.

Cvetković, B., Kalenjuk, B., Tešanović, D., Babić, M. (2016). Gastronomic needs of modern tourists as a problem of tourism market. Researches Review of the Department of Geography, Tourism and Hotel Management, 45-2, 117-131.

Gagić, S., Psodorov, D., Ostojić, G. (2011).Principi inivativne gastronomske ponude, Zbornik radova DGTH, 40, 188-197. 
Gagić, S., Tešanović, D., Kalenjuk, B. (2014). Unapređenje restoraterskog poslovanja primenom inovacionih strategija, Turističko poslovanje, 14, 91-99.

Hey, G. H., Luedemann, G. B. (2001). Food legislation and the protection of allergicand hypersensitive persons: an overview. Journal of Chromatography B: Biomedical Sciences and Applications, 756(1-2):337-42.

Jedrychowski, L., Wichers, H. (2009). Chemical and Biological Properties of Food Allergens. CRC press.

Jones, M. (2001). The Allergy Self-Help Cookbook: Over 350 Natural Foods Recipes, Free of All Common Food Allergens: wheat-free, milk-free, egg-free, corn-free, sugar-free, yeast-free. Paperback.

Kim, J. S., Sinacore, J. M., Pongracic, J. A. (2005). Parental use of EpiPen for childrenwith food allergies. Journal of Allergy and Clinical Immunology, 116(1), 164-168.

Leftwich, J., Barnett, J., Muncer, K., Shepherd, R., Raats, M., Gowland, H., Lucas, J. (2010). The challengesfor nut-allergic consumers of eating out. Clinical and Experimental Allergy.

Lockey, R., Ledford, D. (2008). Allergens and Allergen Immunotherapy, Fourth Edition. CRC press.

Lockey, R., Ledford, D. (2010). Allergens and Allergen Immunotherapy: Subcutaneous, Sublingual, and Oral, Fifth Edition. CRC press.

Martin, C. (2014). The Allergy-Free Pantry: Make Your Own Staples, Snacks, and More Without Wheat, Gluten, Dairy, Eggs, Soy or Nuts. Paperback.

Nollet, L., van Hengel, A. (2010). Food Allergens: Analysis Instrumentation and Methods. CRC press.

Pascal, C. (2005). The Whole Foods Allergy Cookbook, 2nd Edition: Two Hundred Gourmet \& Homestyle Recipes for the Food Allergic Family. Paperback.

Pascal, C. (2009). The Allergen-Free Baker's Handbook. Paperback.

Pascal, C. (2012). Allergy-Free and Easy Cooking: 30-Minute Meals without Gluten, Wheat, Dairy, Eggs, Soy, Peanuts, Tree Nuts, Fish, Shellfish, and Sesame. Paperback.

Pawankar, R., Holgate, S., Lockey, R., Blaiss, M. (2013). WAO White Book on Allergy. World allergy organization.

Sicherer, S., Munoz-Furlong, A., Godbold, J., Sampson, H. (2010). US prevalence of selfreported peanut,tree nut, and sesame allergy: 11 year follow up. Journal of Allergy and Clinical Immunology, 125(6):1322-6

Stojanović, T., Tešanović, D. (2005).Doprinos razumevanju novog pravca u gastronomiji u svetlu savremene restoraterske ponude, Hotellink, 5, 145-151.

Thurnell-Read, J. (2005). Allergy A to Z. Paperback.

Wanich, N., Weiss, C., Furlong, T., Sicherer, S. (2008). Food allergic consumer experience in restaurants andfood establishments. Journal of Allergy and Clinical Immunology, 121/2, S182.

Mušić, E. (2009). Alergije (prepoznavanje, sprečavanje, edukacija). Mozaik knjiga.

Popov-Raljić, J. (2016). Ishrana. Prirodno-matematički fakultet, Departman za geografiju, turizam i hotelijerstvo, Novi Sad. 


\title{
АЛЕРГЕНИ У ХРАНИ КАО ПРОБЛЕМ „УСПЕШНОГ" УГОСТИТЕЉСТВА
}

\author{
Бојана Калењук', Радош Грче', Предраг Тошић", Драган Тешановић' \\ Примљено: 15.02.2017. | Прихваћено: 27.06.2017.
}

\begin{abstract}
АПСТРАКТ: Бирајући и конзумирајући храну у ресторану гост (потрошач) $u$ сам учествује у креирању искуства. То искуство треба да буде позитивно и да представља уживање за сва чула како би се гост вратио у исти угоститељски објекат. Ипак, за особе које су алергичне на неку намирницу, избор и конзумација хране у угоститељским објектима може да прерасте у негативно искуство, да доведе до страха па чак и до негативних или фаталних реакција и посљедица. Управо они могу да отежају успешно половање угоститељског објекта, собзиром да је број алергена у храни сваким даном све већи као и гостију са оваквим проблемима. Рад има задатак да истражи са којим изазовима угоститељски објекати на подручју града Новог Сада се сусрећу, на које могу да одговоре, а на које би жељели одговорити када су алергени у питању.
\end{abstract}

Кључне ријечи: храна, исхрана, алергени, угоститељство

\section{УВОД}

Само задовољан гост може обезбједити профит ресторатерском објекту. УПраво то је оно што је сваким даном све теже. Специфични захтјеви које они носе са собом су сваким даном све бројнији, а последица су различитих фактора, који често ни њима нису познати (Стојановић и Тешановић, 2005; Гагић и сар., 2011; Carvalho de Rezende, Silva, 2014; Гагић и сар., 2014; Cvetkovic et al., 2016). Оно што засигурно отежава успешно пословање су алергени (Bailey et al., 2011; Алексић и cap., 2015).

Брашно, млеко и јаја су до скоро представљали најчешће алергене у храни. Данас је њихов опсег много већи изузев 14 најзаступљенијих. У циљу превазилажења проблема у припреми хране особама које су алергичне на неке од састоја-

\footnotetext{
Универзитет у Новом Саду, Природно-математички факултет, Департман за географију, туризам и хотелијерство, Трг Доситеја Обрадовића 3, 21000 Нови Сад, Србија

" Факултет за туризам и хотелијерство, Универзитет за пословне студије, Бања Лука, БиХ, контакт: pedjat8o@gmail.com
} 
ка, разумевање хране односно познавање њеног састава захтева детаљне контроле које могу да смање ризик, као и алата који могу верификовати адекватну контролу што је јако комплексно (Kim et al., 2005). Број алергија на храну сваким даном расте и отежава угоститељском особљу да сагледају све сегменте у припреми хране и пића како би њихово присуство елиминисали. Први корак у њиховом савладавању је познавање њиховог састава, односно једињења која изазивају алергијске реакције, јер то нису само протеини.

У прирпеми хране у угоститељству потребно је осигурати здравствену исправност хране кроз цео ланац производње: добављач - произвођач - дистрибутер потрошач. Субјекти у пословању с храном надаље морају осигурати да све фазе производње, прераде и дистрибуције хране, које су под њиховом контролом, удовољавају захтјевима везаним за хигијену прописаним Законом. Такође морају успоставити и проводити редовне контроле хигијенских услова у свим фазама производње, прераде и дистрибуције хране, осим на промјени примарне производње и припадајућих дјелатности, у сваком објекту под њиховом контролом, провођењем превентивног поступка самоконтроле, развијеног у складу с начелима састава анализе опасности и критичних контролних тачака. Сваки угоститељски објекат мора бити спреман на одређене измјене начина пословања, тј. припреме хране како би се на адекватан начин уклонио алерген из хране која се нуди госту.

Предмет рада су алергије на храну са којима се сусреће угоститељско особље, и који им задају велике проблеме јер често нису довољно припремљени и едуковани да одговоре на захтеве гостију са овим проблемима.

Задатак рада је да се истраже проблеми везани за алергене са којима се угоститељи сусрећу.

Циљ рада је одредити најзаступљеније алергене и потребу за едукацијом за њихово превазилажење, а све у циљу успешног пословања.

\section{ПРЕГЛЕД ЛИТЕРАТУРЕ}

\section{АЛЕРГИЈА И АЛЕРГЕНИ У ХРАНИ}

Материје које изазивају алергије називају се алергенима, и по начину доспевања у организам груписани су у неколико група. Иако у угоститељству претња могу представљати и респираторни алергени, контактни алергени и слично, највећи проблем представљају нутритивни алергени који улазе у организам путем хране. Процењује се да око 30\% популације има склоност ка алергијским болестима, а сматра се да ће овај број у будућности и даље бити у порасту (Lockey, Ledford, 2008; Pawankar, 2013).

За угоститељско особље је битно напоменути да када организам преосетљиве особе-госта дође у контакт са алергеном у року од неколико минута или сати испољиће се симптоми алергије (Мушић, 2009). Сви симптоми могу бити испољени у благом облику када не ремете радну способност, али и у тежим облицима, па 
и драматичним када угрожавају живот (у случају гушења, анафилактичког шока исл.) (Hey, Luedemann, 2001; Lockey, Ledford, 2010; Martin, 2014).

Битно је разликовати алергију од интолеранције на храну, која подразумјева неспособнос организма да свари одређену храну, то је начешће лактоза (млечни шећер) и целијакија, чија је учесталост у порасту (Sicherer et al., 2010). Алергичност на одређену храну захтјева сталну пажњу при избору хране, што доводи до социјалних ограничења и ретких посета ресторанима (Wanich et al., 2008). Hajчешћи је проблем установити да ли јело које наручују у потпуности не садржи намирнице које изазивају њихову реакцију (Leftwich et al, 2010). Битно jе напоменути да се овде ради о трајном контакту јела са алергеном, не контаминацији која се може ублажити одређеним третманом (термичким) као што је то случај код неких микроорганизама (Nollet, van Hengel, 2010).

\section{СИМПТОМИ АЛЕРГИЈЕ НА ХРАНУ}

Иако се алергијске реакције могу јавити на сваку храну, највећи број реакција се јавља на мали број намирница: млеко, јаја, рибу, шкољке, соју, пшенично брашно, орахе и друго коштуњичаво воће и бобичасто воће (Thurnell-Read, 2005). Алергијске реакције се јављају од неколико минута па до неколико сати након узимања хране на коју је особа алергична. Код нарочито осетљивих особа само мирисање или додиривање хране може изазвати алергијску реакцију. Иста врста хране може да доведе до различитих симптома код различитих особа, али различита врста хране може да доведе до сличних симптома код истог детета (Неу, Luedemann, 2001; Jones, 2001; Jedrychowski, Wichers, 2009; Pascal, 2012).

\section{ХРАНА КОЈА НАЈЧЕШЋЕ УЗРОКУЈЕ АЛЕРГИЈСКЕ РЕАКЦИЈЕ}

Дефинисано је најчешћих четрнаест врста нутритивних алергена који се могу наћи у јелима: кикирики, ораси, ракови, шкољке, морске рибе, јаја, млеко, житарице, соја, сусам, целер, сенф, лупина и сумпор-диоксид (Раљић, 2016). Све чешће су алергије на црвена меса, речну рибу, посебне врсте воћа и поврћа, али и кафу, какао и со.

Алергијске реакције на храну неретко су узроковане одређеним додацима одосно адитивима, конзервансима и бојама. Реакције на адитиве у храни јављају се у око $1 \%$ деце и у $0,01-0,23 \%$ одраслих. Неке од тих супстанци су: натријум бензоат, боја тартразин (жуто обојени напици, слаткиши и сл.), заслађивач аспартам (Pascal 2005; Pascal, 2009; Nollet, van Hengel, 2010).

\section{МЕТОДОЛОГИЈА ИСТРАЖИВАЬА}

Након консултоване домаће и стране литературе истраживање је спроведено провођењем интервјуа међу менаџерима и шефовима кухиња ресторана у Новом Саду. У истраживању ће се корисити дескриптивна метода. Интервју спада у нај- 
чешће коришћен истраживачки поступак за прикупљање података, али се за ову врсту истраживања чинио и као најпогоднији јер укључује интеракцију између испитивача и испитаника и на тај начин даје најпоузданије податке.

Директан интервју је спроведен у 12 ресторана. Интервју се састојао од питања које посебне потребе имају њихови гости и на које могу одговорити и да ли осећају потребу за информисањем или обуком како би могли одговорити потребама својих гостију када су алергени у питању. Добијени резултати су обрађени применог дескриптивне статистике и табеларно и графички уз дискусију приказани у раду.

\section{РЕЗУЛТАТИ РАДА И ДИСКУСИЈА}

\section{АНАЛИЗА НАЈЧЕШЋИХ АЛЕРГИЈА НА ХРАНУ}

Спровођењем истраживања међу угоститељским објектима кроз интервју са менаџерима и шефовима кухиња ресторана на територији града Новог Сада, дошло се до сазнања да ниједан објекат не може да одговори свим захтевима потрошача, али да су се сусретали са свим захтевима, као што се може видети у Табели 1.

Сви менаџери ресторана (100\%) су се сусретали са захтевима за изостављањем намирница које садрже глутен у својим јелима, односно са захтевима оболелих од целијакије, али од тога само 25 \% ресторана може да одговори овим захтевима, а $75 \%$ ресторана би желело да имају знања и услове. Шефови су навели да кухињско особље као замену за пшенично брашно користе пиринчано или кукурузно брашно. Као проблем у припреми јела истичу неспособност детаљњог праћења могућности контаминације јела, јер честице брашна могу доспети у јело путем ваздуха.

Код употребе крављег млека, 50\% се сусретало са захтевима, од тога у $33 \%$ ресторана има у својој понуди јела без лактозе, а 33\% би желело да има таква јела, што није толико тешко извести. За изостављањем јаја 66\% испитаника је изразила специфичне потребе, док потребе може задовољити 50\% ресторана, а $42 \%$ испитаника истичу да би волели да могу да одговоре на потребе гостију, дакле само један ресторан не може и не осећа потребу да одговори на затеве гостију.

У $50 \%$ испитаних ресторана гости су истицали алергичност на јела од риба док само 16\% може да задовољи њихове потребе а $66 \%$ би волело да има услове и знање да одговори овој потреби. Група јела која је сродна јелима од риба су јела од шкољки и ракова, 33\% менаџера ресторана истакло је да се сусрело са захтевима гостију, 50\% је истакло да може одговорити овим захтевима а 25 \% би волело да има услове.

Захтеви за изостављањем кикирикија из јела констатовано је у 25\% угоститељских објеката, у 25\% овакве потребе су примећене и могу их задовољити, док би $42 \%$ волело да има знања и иницијативу за припремом јела за које могу да гарантују да у себи не садрже кикирики ни у траговима. Када је реч о орасима, 25\% се срело са захтевима, $25 \%$ може да задовољи потребе и $25 \%$ би волело да може од- 
Табела 1. Потребе госта за изостављањем јела на које су алергични

\begin{tabular}{|c|c|c|c|c|c|c|}
\hline \multirow[t]{2}{*}{ Врсте алергена } & \multicolumn{2}{|c|}{$\begin{array}{c}\text { Захтеви - потребе } \\
\text { за изостављањем } \\
\text { алергена }\end{array}$} & \multicolumn{2}{|c|}{$\begin{array}{c}\text { Потребе гостију на } \\
\text { које ресторани могу } \\
\text { одговорити }\end{array}$} & \multicolumn{2}{|c|}{$\begin{array}{c}\text { Алергени за које } \\
\text { би желели да имају } \\
\text { могућности и знања } \\
\text { да их елиминишу из } \\
\text { тражених јела }\end{array}$} \\
\hline & $\begin{array}{c}\text { Број } \\
\text { ресторана }\end{array}$ & $\%$ & $\begin{array}{c}\text { Број } \\
\text { ресторана }\end{array}$ & $\%$ & $\begin{array}{c}\text { Број } \\
\text { ресторана }\end{array}$ & $\%$ \\
\hline $\begin{array}{l}\text { Глутен (пшеница, } \\
\text { раж, јечам, зоб) }\end{array}$ & 12 & 100 & 3 & 25 & 9 & 75 \\
\hline Кравље млеко & 6 & 50 & 4 & 33 & 4 & 33 \\
\hline Jaja & 8 & 66 & 6 & 50 & 5 & 42 \\
\hline Рибе & 6 & 50 & 2 & 16 & 8 & 66 \\
\hline Шкољке, ракови & 4 & 33 & 6 & 50 & 3 & 25 \\
\hline Кикирики & 3 & 25 & 3 & 25 & 5 & 42 \\
\hline Ораси & 3 & 25 & 3 & 25 & 3 & 25 \\
\hline $\begin{array}{l}\text { Остало језграсто } \\
\text { воће (бадем, } \\
\text { лешник, пистаћи) }\end{array}$ & 4 & 33 & 3 & 25 & 3 & 25 \\
\hline Coja & 2 & 16 & 1 & 8 & 4 & 33 \\
\hline Сусам & 3 & 25 & 2 & 16 & 1 & 8 \\
\hline Целер & 4 & 33 & 4 & 33 & 2 & 16 \\
\hline Сенф & 2 & 16 & 2 & 16 & 5 & 42 \\
\hline $\begin{array}{l}\text { Лупина } \\
\text { (вучији боб) }\end{array}$ & 1 & 8 & 1 & 8 & 0 & 0 \\
\hline $\begin{array}{l}\text { Сумпор-диоксид } \\
\text { и сулфити }\end{array}$ & 1 & 8 & 0 & 0 & 0 & 0 \\
\hline
\end{tabular}

Извор: Истраживање аутора

говорити потребама гостију када би их ови исказали. Алергију коју изазива конзумирање осталог језграстог воћа односно бадема, лешника и пистаћа пре свега истакло је 33\% менаџера објеката као захтев својих гостију, 25\% може да гарантује квалитет услуге кроз припрему оваквог јела својим гостима, а 25\% би желело да стекне знања и услове.

Coja се често користи као замјена за животињске протеине, и налази се у траговима различитих прехрамбених производа, само два ресторана односно 16\% испитаних су забележене потребе за изостављањем, један од ова два ресторана може одговорити потребама а $33 \%$ би желели да могу, од њих управо један је онај објекат код кога је менаџер истакао да се сусрео са захтевом али није могао да изађе у сусрет захтеву госта.

Изостављање сусама је затражено у 25\% испитаних објеката, два ресторана су спремни да припреме јело а један ресторан би волело да има знање и опремљеност за тако нешто. 
Целер би да из јела изоставе гости $33 \%$ испитаних угоститељских објеката, такође 33\% је спремно да помогне госту при оваквом захтеву а 16\% је заинтересовано за информацијама како да уколико се сусретну са оваквим захтевом, помогну госту.

Сенф се као намирница доста користи, а у 16\% објеката је забележен захтев за изостављањем ове намирнице из припреме јела, такође управо ти испитаници су истакли да су спремни да замене и изоставе сенф, односно слачицу из припреме специјалитета, 42\% шефова је истакло да би желело да буде припремљено уколико се сусретне са оваквим захтевом.

Два узрочника алергијских реакција која се срећу у најмањој мери су лупина и сумпор-диоксид. Лупина је позната као биљка која ефикасно може заменити соју, због високог удела протеина, па је зато често саставни део различитих кобасичарских производа. Сумпор-диоксид (SO2) и сулфити су адитиви из групације Е 220, Е 221-228 и користе се код конзервисања воћа и поврћа, ракија и вина. Захтеви за изостављањем ова два састојка су констаована у по једном објекту. Када је реч о лупини менаџер објекта где је забележена потреба за њеним изостављањем истиче да је то могуће, док менаџер објекта где је гост истакао осетљивост на сумпор-диоксид истиче како на жалост не могу одговорити на ову потребу, услед ретких захтева а и познавања ових намирница као изазивача алергија, ни један менаџер није истакао како би нужно волео да замара знањем своје особље, односно да троши средства у набавци опреме или намирница које ће ефикасно решити проблем. Битна је чињеница да је довољно само детаљно пратити декларације производа које набављају за припрему јела на којима ови састојци морају бити означени, што је много лакше од припреме јела без глутена.

Као своју слабост угоститељи су навели недовољну информисаност о најчешћим алергенима, али и жељу о информисаности кроз неку обуку која би била организована у виду упознавања најчешћих алергена у храни и начина на које они делују и да би можда то деловало подстицајно да допуне своје ресторанске понуде разноврснијим јелима. Приликом услуживања гостију који су алергични на неку намирницу, гост наглашава на шта је алергичан и води се строга пажња у преносу информације. Међутим ресторани често немају стандардизоване процедуре рада, као ни рецептуре, немају ни посебне просторије за припрему хране, тако да је лако доћи до контаминације. На здравствене потребе одређене групе болесника угоститељи нису довољно едуковани, али кроз јасне смернице гостију труде се да одговоре овим захтевима, што не гарантује сигурност.

\section{АНАЛИЗА СПЕЦИЈАЛНИХ ЗАХТЕВА ПОТРОШАЧА У ПОГЛЕДУ АЛЕРГЕНА}

Посматрајући захтеве потрошача који су приказани у графикону 1 , може се констатовати да су најчешћи захтеви за храну без глутена (20\%), а затим јаја (14\%), након чега следе млеко и моркска риба, са свим осталим случајевима се угоститељи много ређе сусрећу. 


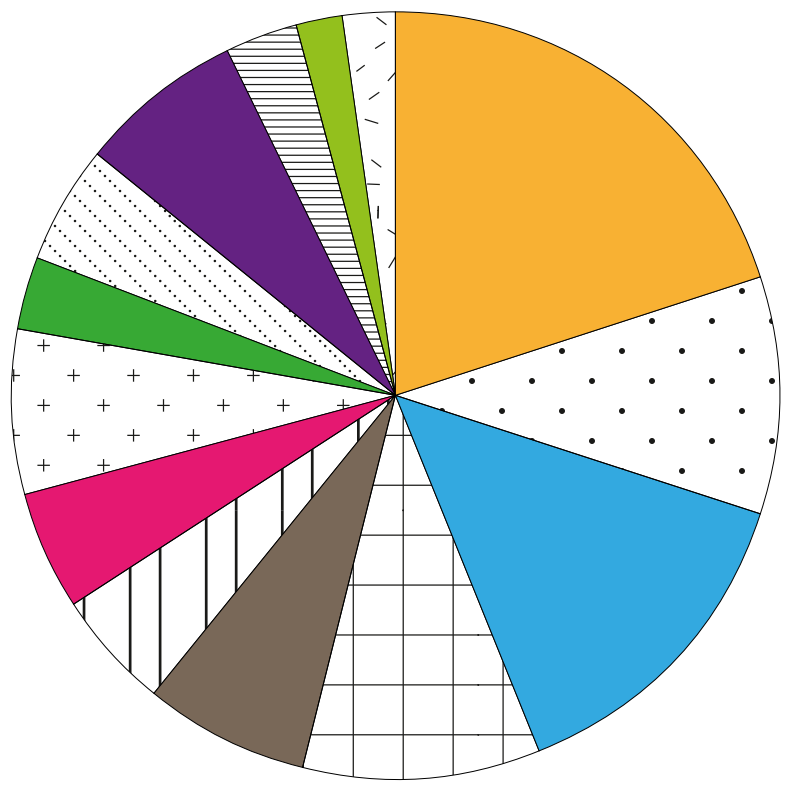

Глутен

- Млеко Jaja

( Морска риба

Шкољке и ракови

(1) Кикирики

O Oраси

( Језграсто воће

- Coja

$\because$ Сусам

Ц Целер

Сенф

Лупин

Сулфити

График 1. Захтеви за изостављањем алергена у јелима

\section{АНАЛИЗА МОГУЋНОСТИ ПРИПРЕМЕ ХРАНЕ БЕЗ АЛЕРГЕНА}

Ако се узме у обзир само реч менаџера и шефа кухиње као одговорног лица, без детаљне контроле у раду може се констатовати да ресторани у највећем проценту могу да одговоре потребама потрошача који су алергични на јаја и морску рибу (15\%), што се заједно са осталим могућностима види у графикону 2.

\section{АНАЛИЗА ЖЕЉА МЕНАЏМЕНТА ДА ОДГОВОРЕ СПЕЦИЈАЛНИМ ЗАХТЕВИМА ЗА ХРАНОМ БЕЗ АЛЕРГЕНА}

Посматрати кроз призму резултате прва два графика примећено је да би менаџери објеката који немају знања и средства за елиминисање глутена волели да их стекну, што је похвално. Поред тога велики број испитаника је заинтересован да стекне знања и могућности за елиминисање рибе и сенфа као алергена, како због њихове честе употребе, тако и због тога што је њихова замена тешка.

У графикону 3 приказано је у којем проценту би испитаници желели да имају знања и средства да одговоре на захтеве својих гостију, где је акценат стављен на глутен и морску рибу, али и припрему јела без кикирикаија, сенфа, јаја и млека. 


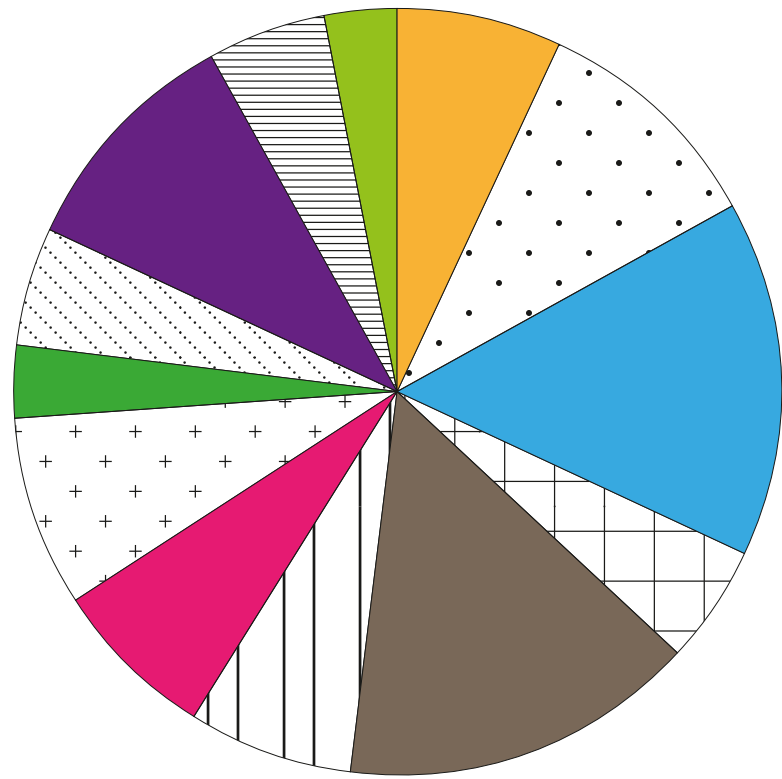

Глутен

$\odot$ Млеко

Jaja

$\bigoplus$ Морска риба

Шкољке и ракови

(1) Кикирики

Oраси

( ) Језграсто воће

Coja

$\bigcirc$ Сусам

Целер

$\vartheta$ Сенф

Лупин

(-) Сулфити

График 2. Могућност припреме јела без поједини алергена

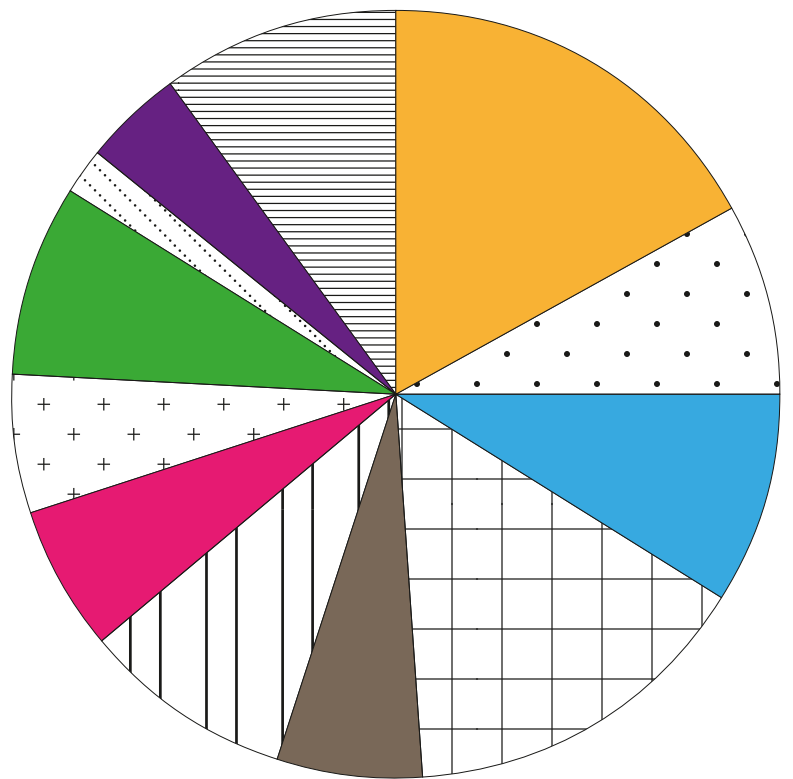

Глутен

- Млеко

Jaja

$\bigoplus$ Морска риба

Шкољке и ракови

(1) Кикирики

Oраси

(†) Језграсто воће

Coja

$\bigcirc$ Сусам

Целер

$\vartheta$ Сенф

Лупин

(-) Сулфити

График 3. Алергени за које би желели да имају услове и знања да их изоставе 


\section{ЗАКЉУЧАК}

На основу истражене литературе из области савремених трендова у угоститељству и алергенима као кључном проблематиком уз спроведено истраживање на територији града Новог Сада дошло се до сљедећих заључака:

- Алергија на глутен представља најчешћу потешкоћу успешног пословања у 100\% испитаних објеката а алергија на јаја (66\% испитаних) односно на кравље млеко и рибе (50\% испитаних) спадају у доста честе проблеме, за разлику од алергиија на лупин или сумпор-диоксид које су једва познате угоститељским радницима.

- Оно што је похвално је што је већина оних који су забележили захтеве на њих могли и да одговоре. То међутим није случај са глутеном који због чињенице да се може наћи у ваздуху представља тежак алерген за изостављање па тако само 25\% испитаних може одговорити изостављањем глутена. Ипак, код других алергена само поједини испитаници су истакли да нису у стању да задовоље потребе гостију односно за неке типове алергена сви који су се сусретали могли су и да их изоставе за потребе конкретног госта.

- Такође је похвално и то да велики број угоститељских објеката који се нису сусретали са захтевима за изостављањем одређених алергена би волело да буде спремно за такву ситуацију уколико до ње дође. Присутна је и жеља да се стекну знања и могућности за испуњење оних захтева гостију који нису могли бити претходно испуњени. Свих 75\% испитаних који нису у стању да одговоре на потребе изостављања глутена би желели да јесу. И код већине осталих алергена менаџери и шефови су истакли заинтересованост да на најефикаснији начин одговоре на захтеве гостију. Но, ипак примећена је још увек не довољна информисаност менаџера и шефова а поготово особља о томе шта алергени представљају, који су најчешћи алергени и како их заменити или изоставити. Решење за такве ситуације су знали менаџери или одређени искусни појединци док је већина била прилично неинформисана и неспремна. Из тог разлога је потребно радити са особљем али и са менаџерима, преносити им информације јер је здравље за појединца најважније а угоститељски објекат као место уживања не сме бити извор нарушавања здравља.

\section{ЗАХВАЛНИЦА}

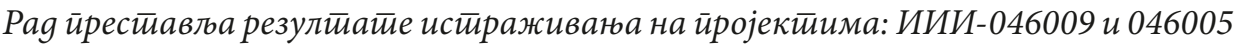
које финансира Минисииарстиво за науку и иеехолочки развој Рейублике Србије, и 142-451-2669/2017 који финансира Покрајински секретиаријати за високо образовате и научноистираживачку делайности. 


\section{ЛИТЕРАТУРА}

Алексић, М., Попов-Раљић, Ј., Милановић, С. (2015). Алергени као хемијски ризици у систему безбедности хране у угоститељству и њихово означавање, Хотеллинк, 25-26, 247-256.

Bailey, S., Albardiaz, R., Frew, A. J., Smith, H. (2011). Restaurant staff's knowledge of anaphylaxis and dietary care of people with allergies. Clinical and Experimental Allergy

Carvalho de Rezende, D., Silva, M. (2014). Eating out and experiential consumption: a typology of experience providers. British Food Journal, 116/1, 91 - 103.

Cvetković, B., Kalenjuk, B., Tešanović, D., Babić, M. (2016). Gastronomic needs of modern tourists as a problem of tourism market. Researches Review of the Department of Geography, Tourism and Hotel Management, 45-2, 117-131.

Гагић, С., Псодоров, Д., Остојић, Г. (2011). Принципи иновативне гастрономске понуде, Зборник радова ДГТХ, 40, 188-197.

Гагић, С., Тешановић, Д., Калењук, Б. (2014). Унапређење ресторатерског пословања применом иновационих стратегија, Туристичко пословање, 14, 91-99.

Hey, G. H., Luedemann, G. B. (2001). Food legislation and the protection of allergic and hypersensitive persons: an overview. Journal of Chromatography B: Biomedical Sciences and Applications, 756(1-2): 337-42.

Jedrychowski, L., Wichers, H. (2009). Chemical and Biological Properties of Food Allergens. CRC press.

Jones, M. (2001). The Allergy Self-Help Cookbook: Over 350 Natural Foods Recipes, Free of All Common Food Allergens: wheat-free, milk-free, egg-free, corn-free, sugarfree, yeast-free. Paperback.

Kim, J. S., Sinacore, J. M., Pongracic, J. A. (2005). Parental use of EpiPen for children with food allergies. Journal of Allergy and Clinical Immunology, 116(1), 164-168.

Leftwich, J., Barnett, J., Muncer, K., Shepherd, R., Raats, M., Gowland, H., Lucas, J. (2010). The challenges for nut-allergic consumers of eating out. Clinical and Experimental Allergy.

Lockey, R., Ledford, D. (2008). Allergens and Allergen Immunotherapy, Fourth Edition. CRC press.

Lockey, R., Ledford, D. (2010). Allergens and Allergen Immunotherapy: Subcutaneous, Sublingual, and Oral, Fifth Edition. CRC press.

Martin, C. (2014). The Allergy-Free Pantry: Make Your Own Staples, Snacks, and More Without Wheat, Gluten, Dairy, Eggs, Soy or Nuts. Paperback.

Nollet, L., van Hengel, A. (2010). Food Allergens: Analysis Instrumentation and Methods. CRC press.

Pascal, C. (2005). The Whole Foods Allergy Cookbook, 2nd Edition: Two Hundred Gourmet \& Homestyle Recipes for the Food Allergic Family. Paperback.

Pascal, C. (2009). The Allergen-Free Baker's Handbook. Paperback.

Pascal, C. (2012). Allergy-Free and Easy Cooking: 30-Minute Meals without Gluten, Wheat, Dairy, Eggs, Soy, Peanuts, Tree Nuts, Fish, Shellfish, and Sesame. Paperback.

Pawankar, R., Holgate, S., Lockey, R., Blaiss, M. (2013). WAO White Book on Allergy. World allergy organization. 
Sicherer, S., Munoz-Furlong, A., Godbold, J., Sampson, H. (2010). US prevalence of self-reported peanut, tree nut, and sesame allergy: 11 year follow up. Journal of Allergy and Clinical Immunology, 125(6):1322-6

Стојановић, Т., Тешановић, Д. (2005). Допринос разумевању новог правца у гастрономији у светлу савремене ресторатерске понуде, Хотеллинк, 5, 145-151.

Thurnell-Read, J. (2005). Allergy A to Z. Paperback.

Wanich, N., Weiss, C., Furlong, T., Sicherer, S. (2008). Food allergic consumer experience in restaurants and food establishments. Journal of Allergy and Clinical Immunology, 121/2, S182.

Мушић, Е. (2009). Алергије (препознавање, спречавање, едукација). Мозаик књига.

Попов-Раљић, J. (2016). Исхрана. Природно-математички факултет, Департман за географију, туризам и хотелијерство, Нови Сад. 